\title{
来院時に異常姿勢を呈したび漫性脳損傷の検討
}

$\begin{array}{lllllllll}\text { 柴 田 將 良 松 前 光 紀 } & \text { 下 } \text { 雅 } & \text { 美 } \\ \text { 石 坂 秀 夫 } & \text { 白 } & \text { 水 秀 樹 } \text { 津 } & \text { 金 } & \text { 隆 } & \end{array}$

\section{Clinical Analysis of Diffuse Brain Injury Patients with Abnormal Posture \\ by}

Masayoshi Shibata, M.D., Mitsunori Matsumae, M.D., Masami Shimoda, M.D., Hideo Ishizaka, M.D., Hideki Shiramizu, M.D., and Ryuichi Tsugane, M.D.

from

Department of Neurosurgery, Tokai University School of Medicine

Although it is well known that patients with diffuse brain injury (DBI) associated with abnormal posture have a dismal outcome, some patients in our experience have shown a favorable outcome.

Using multivariate statistical analysis, we examined prognostic factors in 30 DBI patients with abnormal posture who underwent magnetic resonance imaging (MRI) within 3 weeks after admission. The items investigated as outcome-predicting factors were the correlations between the outcome 6 months after injury and general physical condition, neurological findings at admission, and neuroradiological findings.

Overall, 16 patients (53\%) achieved a favorable outcome and $14(47 \%)$ had on unfavorable outcome. Factors that were correlated with a favorable outcome included:1) absence of lesions in the ventral upper midbrain on MRI, and 2) duration of abnormal posture of less than 7 days after injury.

This study suggests that the outcome of DBI patients cannot be extrapolated immediately up on admission. Therefore, we conclude that intensive care and treatment should be indicated even if the patients showed abnormal posture in DBI cases. MRI examination in the earlyphase and detailed observation of nerological signs are also important.

(Received April 24, 1998; accepted January 15, 1999)

Key words : diffuse brain injury, abnormal posture, outcome

Jpn J Neurosurg (Tokyo) 8: 526-531, 1999

\section{はじめに}

一般に重症頭部外傷に扔いて異常姿勢を伴う場合の転

帰は不良であるとされている。しかし，臨床の場におい てその存在と転帰が一致しない症例もあり，転埽の推定 に苦虑することをしばしば経験する，今回著者らは，初 診時に異常姿勢を呈した diffuse brain injury（DBI）の 症例において, 来院時の神経学的所見, 全身状態㧍よび 神経放射線学的所見を検討し, 転帰を推察可能な項目を retrospective に分析した。

\section{対象および方法}

対象は 1991 年以降，東海大学病院に搬入された頭部 外傷患者のうち Glasgow Coma Scale (GCS) が 8 点 以下の状態が 6 時間以上持続し, CT 上意識障害を生じ 得る明らかな mass effectを伴わない症例で, 初診時異 常姿勢を認め, 受傷から 3 週間以内に MRI を施行でき

東海大学医学部脳神経外科 $/$ T 259-1193 伊勢原市望星台. (連絡先：柴田將良)

Address reprint requests to: Masayoshi Shibata, M.D., Department of Neurosurgery, Tokai University School of Medicine, Bohseidai, Isehara-shi, Kanagawa 259-1193, Japan 
Table 1 Outcome in head injury patients with abnormal posture

\begin{tabular}{lccccc}
\hline & GR & MD & SD & PVS & Death \\
\hline No. of cases & 1 & 15 & 5 & 9 & 0 \\
Paresis & 0 & 7 & 5 & 9 & 0 \\
\hline GR: good recovery & MD: moderate & disability \\
SD: severe disability & PVS: persistent vegetative \\
state & & &
\end{tabular}

た 30 例とした。異常姿勢は除脳姿勢, 除皮質姿勢, そ の混合姿勢, 両側下肢のみの異常伸展姿勢に分けた。転 帰は受傷 6 力月後の時点での状態を Glasgow Outcome Scale（GOS）を用いて評価し, good recovery (GR), moderate disability (MD) を転帰良好群, severe disability (SD), persistent vegetative state (PVS), death 転帰不良群の 2 群に分けて評価した。

各症例において, 年齢, 来院時 vital sign, 動脈血力゙ 又 (ABG) 所見, 意識状態, 瞳孔所見, 対光反射, 異 常姿勢の種類, 頭蓋骨骨折の有無, 頭蓋内圧, 意識障害 の持続時間, CT 所見, MRI 所見と転㷌を比較検討す ることで転帰を推定でき得る因子を分析した。CT 所見 は来院時施行されたものを用いて評価し, 今回検討した MRI の撮影時期は受傷後 3〜21 日, 平均 10.3 日に施行 されたものである。なお統計学的解析には Fisher の直 接確率計算法, 扔よびロジスチック回帰による多変量解 析を用いて行った。

治療に関しては必要に応じて頭蓋内圧および内頸静脈 酸素飽和度を測定しながら, 過換気療法, 高浸透圧療 法，全身管理を中心に行った。低体温療法を施行したの は 7 例であり，32〜34 $\mathrm{C}$ を 3 8 日間継続した。また， 経過中に著明な体温上昇を認めたものには $37^{\circ} \mathrm{C}$ 前後に 冷却ブランケットを用いて調節した。その際シバリング が強い症例には筋弛緩剤を投与し，呼吸器で補助呼吸を 適宜行った。

\section{結 果}

全症例に㧍ける転帰は良好群 16 例，不良群 14 例であ った（Table 1). GR となったのは1例のみであり， MD となったのが 15 例と全症例の半数を占めた。死亡 例はなかったが，麻㽽の残存した症例は 21 例（70\%） に認められ，MD群ではその約半数に麻痺が残った。年 齢については 15 例が 20 歳末満であり，30 歳以上の症 例は 3 例とほとんどみられず，65歳以上の高齢者は 1 例のみであった。この年齢の分布は，重症 DBI 例が若 年に多いことと，高齢者の場合には MRI を施行する以
Table 2 Clinical features and outcome in head injury patients with abnormal posture

\begin{tabular}{|c|c|c|c|}
\hline \multirow{2}{*}{ Variable } & \multicolumn{2}{|c|}{ Outcome } & \multirow{2}{*}{ p-value } \\
\hline & \multicolumn{2}{|c|}{$\mathrm{F} \quad \mathrm{U}$} & \\
\hline No. of cases & 16 & 14 & \\
\hline Age $\quad<20 \mathrm{yrs}$ & 9 & 6 & NS \\
\hline \multicolumn{4}{|l|}{ Vital signs on admission } \\
\hline Hypotention $\quad \mathrm{BP}<90 \mathrm{mmHg}$ & 2 & 2 & NS \\
\hline Tackycardia $\quad H R>130 / \mathrm{min}$ & 4 & 1 & NS \\
\hline Abnormal respiration & 15 & 13 & NS \\
\hline Hyperthermia $\quad>39^{\circ} \mathrm{C}$ & 9 & 10 & NS \\
\hline \multicolumn{4}{|l|}{$\mathrm{ABG}$ finding on admission } \\
\hline $\mathrm{PaO}_{2}<60 \mathrm{mmHg}$ & 4 & 2 & NS \\
\hline $\mathrm{PaCO}_{2}>50 \mathrm{mmHg}$ & 3 & 0 & NS \\
\hline \multicolumn{4}{|l|}{ Neurological status } \\
\hline GCS $\quad<6$ & 8 & 12 & NS \\
\hline Abnormal pupil & 8 & 11 & NS \\
\hline Light reflex & 16 & 10 & 0.03 \\
\hline \multicolumn{4}{|l|}{ Postures } \\
\hline Bil. decerebrate & 3 & 5 & NS \\
\hline Bil. decorticate & 2 & 4 & NS \\
\hline Hemi. decerebrate & 3 & 3 & NS \\
\hline Hemi. decorticate & 2 & 1 & NS \\
\hline Mix & 2 & 1 & NS \\
\hline Bil. lower limbs & 4 & 0 & 0.04 \\
\hline Skull fracture & 6 & 8 & NS \\
\hline ICP $\quad \geqq 20 \mathrm{mmHg}$ & 1 & 5 & NS \\
\hline $\begin{array}{l}\text { Abnormal posture within } 7 \text { days } \\
\text { after injury }\end{array}$ & 8 & 1 & 0.01 \\
\hline & heart rate $A B G$ : arterial blood gas GCS: \\
\hline \multicolumn{4}{|c|}{$\begin{array}{l}\text { Glasgow Come Scale ICP: intracranial pressure } \\
\text { Significance was determined according to the Fi- } \\
\text { sher's exact test. }\end{array}$} \\
\hline
\end{tabular}

前に死亡することが多いためと思われた。また多発外傷 合併例はなかった。

\section{1 全身状態との関連}

来院時血圧 $90 \mathrm{mmHg}$ 以下の症例は 4 例のみであり, 転帰との有意な相関はなかった (Table 2). 異常呼吸は 呼吸回数が 12 回以下, 24 回以上, 呼吸リズムが失調性 であるものとし，転㷌にかかわらず全 30 例中 28 例と 9 割以上の症例で異常呼吸が認められ, なかでも過換気で あったものが最多であった。高体温は受傷から 12 時間 以内に $39^{\circ} \mathrm{C}$ 以上に体温上昇がみられたものとした。19 例 $(63 \%)$ に存在したが，その半数は転帰良好であり， 2 群に有意差はなかった。ABG 所見では低酸素血症が 6 例，高二酸化炭素血症が 3 例に存在したが，転帰との 相関はなかった。 
Table 3 Initial CT findings and outcome in head injury patients with abnormal posture

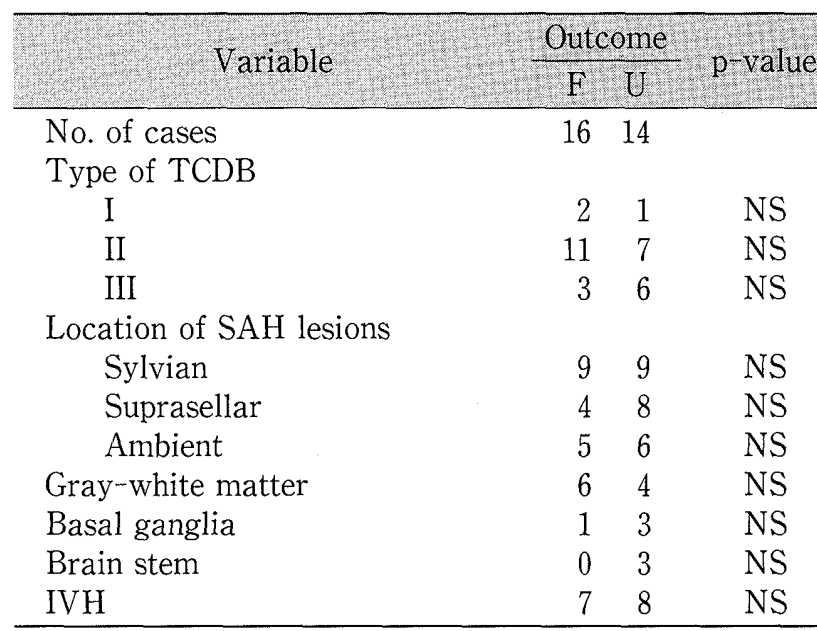

NS: not sigificant TCDB: Traumatic Coma Data Bank SAH: subarachnoid hemorrhage IVH: intraventricular hematoma

Significance was determined according to the Fisher's exact test.

$\mathrm{F}$ : favorable outcome

$\mathrm{U}$ : unfavorable outcome

\section{2 神経所見との関連}

入院時 GCS は 5 を境界に検討したが，転㷌と有意な 相関はなかった (Table 2). 瞳孔異常は 30 例中 19 例 （63\%）であり，そのうち瞳孔不同が 17 例，両側縮瞳 が 2 例，両側朣孔散大例はなく，瞳孔所見と転帰に相関 はなかった。一方，対光反射が左右いずれかでも存在し た症例は有意に転帰良好群で多かった。

異常姿勢の種類はさまざまであり，統計学的有意差を 認めたのは両側下肢の伸展位のみの場合に転帰が良好で ある点であった。

異常姿勢の持続期間と転帰との相関を検索した．改善 の評価については，異常位を呈した四肢のいずれかに自 発運動が出現するまでの期間とした。週単位で受傷〜4 週間まで検討したところ，最も短期間で相関を示したの は 1 週間以内であり，転帰良好群の 16 例中 8 例が自発 運動が出現した。

\section{3 頭蓋骨骨折および頭蓋内圧との関連}

頭蓋骨骨折は 14 例に存在したが，明らかな相関は示 さなかった（Table 2). 頭蓋内圧測定は 21 例で施行さ れ, 初期平均圧が $20 \mathrm{mmHg}$ 以上と高值であったのは 21 例中 6 例 $(29 \%$ ）に存在した。頭蓋内圧え進を認め た 6 例のうち 5 例が転帰不良であったが，症例数が少な いためか統計学的有意差はなかった。
Table 4 MRI findings and outcome in head injury patients with abnormal posture

\begin{tabular}{lccc}
\hline \multicolumn{1}{c}{$\begin{array}{c}\text { Variable } \\
\text { Navorable Unfavorable }\end{array}$} & $\begin{array}{c}\text { F-value } \\
\text { outcome }\end{array}$ & outcome & p- of cases \\
Location of lesions & 16 & 14 & \\
$\quad$ Cortex & & & \\
$\quad$ Frontal & 7 & 8 & NS \\
$\quad$ Near motor & 7 & 6 & NS \\
Perilateral ventricle & 2 & 4 & NS \\
Gray-white matter & 8 & 9 & NS \\
Basal ganglia & 1 & 7 & 0.01 \\
Thalamus & 1 & 5 & NS \\
Corpus callosum & 12 & 10 & NS \\
Midbrain & & & \\
$\quad$ Dorsal & 3 & 8 & NS \\
$\quad$ Ventral and/or & 0 & 9 & 0.00 \\
$\quad$ lateral $(\mathrm{p}<0.01)$ & & & \\
$\quad$ Central & 0 & 5 & 0.01 \\
Pons & 0 & 5 & 0.01 \\
Cerebellum & 3 & 1 & NS \\
\hline
\end{tabular}

NS: not significant

Significance was determined according to Fisher's exact test.

\section{CT 所見との関連}

Traumatic Coma Data Bank (TCDB) のCT分 類12)では II 型が全例中 18 例 $(60 \%)$ と最多であった が，III 型が 9 例（30\%）と比較的多く認められ，その 転帰は 60 \%以上で不良であった（Table 3).

一方，クモ膜下出血（SAH）についてはその部位別 に検討した。存在部位はそれぞれシルビウス裂に 18 例, 鞍上槽に 12 例，迂回槽に 11 例であった。すべての部位 で転帰との相関はなかったが，鞍上槽に SAH が存在し た症例は 12 例中 8 例 $(67 \%)$ で転帰不良となる傾向に あった。さらに脳実質損傷については出血性㐨よび非出 血性病変を併せて病変部位別に転帰と比較した。最も多 く病変がみられた部位は灰白質一白質境界部の 30 例中 10 例 $(33 \%)$ で，その半数以上は転帰良好であった。 しかし，脳幹部病変が存在したのは 3 例にすぎなかった が，全例が出血性でかつ転帰も不良となった。

脳室内出血（IVH） は全症例中の 15 例（50\%）と高 頻度に存在したが，転帰との相関はなかった。

\section{$5 \mathrm{MRI}$ 所見との関連}

皮質病変については皮質のみのものはなく，皮質下に も伸展して打り，前頭葉の運動野周辺に多く存在した (Table 4). その約半数は出血性病変であった。灰白質一 白質部および基底核部の損傷は CT では指摘できず, MRIにおいて明らかとなった病変が多かった。なかで も基底核部については CT で 4 例，MRI では 8 例と 2 
Table 5 Stepwise logistic regression analysis of favorable outcome in head injury patients with abnormal posture

\begin{tabular}{cccc}
\hline Variales & Odds Ratio & $95 \% \mathrm{Cl}$ & $\mathrm{p}$-value \\
\hline $\begin{array}{c}\text { Absence of ventral } \\
\text { midbrain lesion }\end{array}$ & 2.800 & $1.387-5.654$ & $<0.0001$ \\
$\begin{array}{c}\text { Abnormal posture } \\
\text { within } 7 \text { days } \\
\text { after head injury }\end{array}$ & 2.425 & $1.164-4.982$ & 0.0286 \\
\hline
\end{tabular}

$\mathrm{CI}$ : confidence interval

倍の頻度で認められ，同部病変の存在は転帰と相関を示 した. 脳梁損傷は 30 例中 22 例 $(73 \%$ ） と最も高頻度 に認められたが転帰との相関はなかった。

脳幹部の病変の部位を中脳蓋部を背側, 大脳脚部を腹 側，中脳被蓋の外側と正中部を側方と中心部，橋に分け て検討した。背側部の病変は 11 例に存在したが，背側 のみであったのは 1 例しかみられず，転帰良好であっ た。また，損傷が背側と側方にみられたのは 11 例中 4 例であり，半数が転㷌良好となった。それに比較して腹 側部に損傷が存在した場合は，全例で転帰不良となっ た.

\section{6 予後推定因子の検討}

多変量解析で有意な転帰良好因子は, (1) MRI 上中脳 腹側部に病変を認めないこと, (2) 異常姿勢の継続時間 が 7 日以内であることの 2 項目であった（Table 5)。さ らにこの 2 項目と最終的な麻痺の残存, および意識状態 との関係をみると 2 週間以上の異常姿勢が継続した症例 では全例に麻痺が認められ，4 週間以上存在したもので 従命可能なまで意識が改善したのは 7 例中 2 例であっ た。また, 中脳腹側部に病変が認められた 9 例中全例に 麻痺が残存し，従命可能となったのは 3 例のみであった

(Table 6).

\section{考 察}

前世紀末から異常姿勢は動物実験において中枢神経系 を種々の高さで切断することにより観察された。なかで も有名なのが Sherrington ${ }^{16)} に よ り$ 行われたネコの上 丘と下丘の間で脳幹を切断した際に生じた除脳姿勢であ る。一方, 頭部外傷の臨床の場においては，いわゆる脳 幹症状としての除脳硬直を伴った DBI は最重症型であ り，その転帰は不良であるとされている7)13)。しかし著 者らの検討した症例は，典型的な除脳硬直を示したもの は約 $25 \%$ \%あったとはいえ，除脳硬直を含めた異常姿 勢が来院時に認められながら意外にもその転帰は約半数
Table 6 Final neurological findigs and correlative factors by stepwise logistic regression analysis

\begin{tabular}{ccc}
$\begin{array}{c}\text { Duration of } \\
\text { Abnormal posture }\end{array}$ & $\begin{array}{c}\text { Existence of } \\
\text { paresis }\end{array}$ & $\begin{array}{c}\text { Possibility of } \\
\text { veral command }\end{array}$ \\
\hline 1 week $\quad(n=9)$ & 2 & 9 \\
$1-2$ weeks $(n=5)$ & 3 & 4 \\
$2-3$ weeks $(n=6)$ & 6 & 4 \\
3-4 weeks $(n=3)$ & 3 & 1 \\
4 weeks $(n=7)$ & 7 & 2 \\
\hline Ventral midbrain lesion & 9 & 3 \\
on MRI $(n=9)$ & \\
\hline
\end{tabular}

が良好で死亡例はなかった。またこの結果は，雨側除脳 硬直を示した症例の中でも中脳病変が証明できなかった ことからも, Jennettら ${ }^{10)}$ のいう四肢の異常伸展の存在 と上位脳幹病変の局在性には疑問があるとする指摘を支 持するものと思われる。一方，除脳硬直と似た姿勢とし て，呼吸のパターンや脈拍の変動に伴い突然に四肢の異 常伸展位が生じる tonic fits とよばれる状態の存在も知 られている17)。この発生機序は血液や感染などにより 脳幹が直接刺激されるため生じた筋攣縮であり，上位中 枢から抑制がとれた解放現象である除脳硬直とは本質的 に異なる状態とされている5)。また，除脳硬直の場合は 痛覚なぞの刺激によって伸展位が増強されるが，tonic fitsの場合はなんら刺激もなく自然に誘発される。今回 の症例の中でMR I 上脳幹病変が認められないにもかか わらず，雨側四肢伸展姿勢を呈した 3 例中 2 例に脳幹周 国の SAH と第 4 脳室内血腫がみられ，この病態が含ま れていた可能性も考えられた。

従来，重症頭部外傷例においては損傷部位が多発性で あることが多いため，典型的な除脳，除皮質硬㨁姿勢を 必ずしも呈さないとされている21.著者らの検討では異 常姿勢の種類はさまざまではあったが，全例において下 肢の過伸展を伴うという大きな特徵を有していた。損傷 部位の局在は中脳の広範にわたり存在したのは 9 例にと ぞまったが，予想に反して運動野近傍の白質および皮質 損傷が 13 例敒認められた。この結果を裏づける報告と して Holbourn ${ }^{8)}$ は，ゼラチンモデルで回転加速度を加 えた場合 shearing force は皮質下で最大であるとし， Lindenberg ら ${ }^{11)}$ は同様の外力は皮質下でも運動野近傍 に強いとしている。一方，益澤ら ${ }^{14)}$ は臨床的に傍矢状 部白質損傷と瘥性片麻痺の関係について報告している が，これらと同様に受傷直後の運動野と運動前野の障害 により解剖学的に下肢に強い筋緊張と反射の六進が生じ て異常伸展位を呈したと推察される。両側下肢の伸展位 のみの症例で転帰が良好であったのは，損傷がこの部位 に限局した可能性が示唆された。加えて，従来DBIに 
運動麻㽻を伴いやすいことは周知の事実であり，著者ら の結果に扔いても $60 \%$ 以上と高頻度に運動麻㾇の残存 がみられたことは，錐体路のいずれかに病変が存在し， 異常姿勢の発現に関与していたものと思われる.

また，著者らの結果で注目すべき全身所見として，体 温の上昇を $60 \%$ 以上に認めたこともきわめて興味深い. 体温中枢は古くから視束前野・前視床下部に存在すると されたが，近年になり中脳，延髄，春髄などにも体温の 統合機能があることが判明している shearing force が強度を増すほどに脳深部に損傷を生じ やすくするため, 体温調節の異常がみられる症例は視床 下部や脳幹に一過性，もしくは永続的な変化が存在する と推察される.しかし, 検討した症例の中で来院直後か ら体温上昇を認めたものはなく, 筋緊張の異常立進が原 因となり反応熱を生じて体温上昇に至った可能性も否定 できない.いずれにしても上昇した体温は脳損傷を二次 的に悪化させることも憂慮され, 異常姿勢を伴うような 頭部外傷例に対しては体温調節を念頭においた治療が必 須と考光られた。

一方，異常瞳孔所見として瞳孔不同が 17 例にみられ， 従来の一次性外傷性動眼神経麻禆の頻度を $1 \%$ 程度とす る報告 ${ }^{15)}$ と比較して高率に存在した。しかし, 意外に も転帰との相関はなく, MRIによって中脳正中から腹 側付近に病変を認めたのは 17 例中 10 例と瞳孔不同の責 任病巣を示唆したものの, 臨床的意義は薄いと考えられ た。また，MRI 上脳幹損傷を伴わないにもかかわらず 中脳周囲にSAH を合併した頻度は高かったことによ り, 単に脳幹周团に血管損傷が生じたと同時に脳槽内に おいて動眼神経損傷が発現したものと思われた。逆に， 両側対光反射が消失していた場合には全例において MRI 上脳幹病変が確認され, 転帰不良であり, 臨床的 に重要な転帰推測因子であった。

$\mathrm{CT}$ 所見の中で $\mathrm{TCDB}$ の $\mathrm{CT}$ 分類が III 型であった 9 例のうち，6例が MRI 上脳幹病変を合併していた。 ま た, 頭蓋内圧元進を示した 6 例中 4 例が脳幹病変を伴っ た TCDB III 型であった. DBI で頭蓋内圧元進を伴う 場合の転帰は不良とされており ${ }^{12)}$, 著者らの検討でも 同様の結果となったが, 初期圧は高值でもそのコントロ ールが不可能であった症例は存在しなかった。このこと から頭蓋内圧六進状態の原因の多くが脳幹病変に基づく 血管調節中枢部の直接損傷による急性脳腫脹であるとす ると，初期圧の卉進は脳幹損傷の結果であり，転帰を左 右するのは頭蓋内圧六進ではなく，その原因の脳幹損傷 である可能性も示唆された。

さて MRI 所見であるが, Adams ら ${ }^{1)}$ は DBI の重症
度について病変の深達度を白質, 脳梁, 脳幹に分けて説 明している。今回は脳幹部に病変を確認できたのは 30 例中 15 例と $50 \%$ であり，これらの症例は中心部に出血 がみられた 1 例を除いて全例でテント上病変を合併して いた，脳梁部を除いて病変の頻度は脳の深部ほど減少し たが, 深部病変の存在する症例は転帰不良となった。 Gentry ら ${ }^{6)}$ は一次性脳幹損傷の原因を, (1) direct superficial laceration or contusion, (2) diffuse axonal injury(DAI), (3) multiple primary petechial hemorrhages, (4) pontomedullary separation に分類し, DAI による損傷部位は中脳背外側に多いとしており, 著者ら の検討においても同様であった。しかし，詳細に病変を みると背側部の病変に加えて外側から腹側へ進展してい た病変が 6 例に認められた。また，脳へルニアなどによ る二次性の脳幹病変に多いとされている背側部にみられ ず外腹側部にのみ損傷が生じていたものが 3 例に認めら れた. 今回の検討では二次性の損傷と同様な中脳腹側部 に病変が認められたものの転帰は明らかに不良であり， 転帰を推察する重要な所見と考えられた.

異常姿勢を呈した頭部外傷の転帰については，瞳孔所 見, 意識障害の程度, 年齢, 異常姿勢の継続時間, 異常 姿勢の種類が重要であるとの報告がある2) 5)，著者ら が統計学的検索をした結果は, 異常姿勢の継続時間はこ れまでの報告を支持するものであり，加えて MRI 所見 が最も予後と相関した。いずれにしても来院時の所見か ら転帰を推定することは困難であるが，半数が転帰が良 好であったことからも，多角的な集中治療が必要であ り，転帰を推定するうえでは，早期に MRI を施行する ことと異常姿勢の経過の観察が重要と考えられた。

\section{文献}

1) Adams JH, Graham DI, Murray LS, Scott G: Diffuse axonal injury due to nonmissile head injury in humans: An analysis of 45 cases. Ann Neurol 12: 557-563, 1982.

2) Bricolo A, Turazzi S, Alexandre A, Rizzuto N: Decerebrate rigidity in acute head injury. $J$ Neurosurg 47 : 680-698, 1977.

3) Bruce DA, Schut L, Bruno LA, Wood JH, Sutton LN : Outcome following severe head injuries in children. $J$ Neurosurg 48:679-688, 1978.

4) Caruselli G, Luongo A: Prognosis of traumatic decerebrated rigidity. Neurosurg Sci 18: 124-132, 1974.

5) Davis RA, Davis L: Decerebrate rigidity in humans. Neurosurgery 10:635-642, 1982.

6) Gentry LR, Godersky JC, Thompson BH: Traumatic brain stem injury: MR imaging. Radiology 171: 177187, 1989.

7) Gennarelli TA: Cerebral concussion and diffuse brain 
injury. Cooper PR (Ed): Head injury, 3rd ed, Williams and Wilkins, Baltimore, 1993, pp. 137-158.

8) Holbourn AHS: Mechanics of head injuries. Lancet 2: 438-441, 1943.

9）堀 哲郎：視床下部と体温調節。神経進歩 31 : 504$519,1987$.

10) Jennett $B$, Plum $F$ : Persistent vegetative state after brain damage. Lancet 1:734-737, 1972.

11) Lindenberg R, Freytag E: The mechanism of cerebral contusions. Arch Pathol Lab Med 69:440-469, 1960.

12) Marshall LF, Marshall SB, Klauber MR, van Berkum Clark M, Eisenberg HM, Jane JA, Luerssen TG, Marmarou A, Foulkes MA: A new classification of head injury based on computerized tomography. $J$ Neurosurg 75 (Suppl): S14-S20, 1991.
13) Marshall LF, Gautille T, Klauber MR, Eisenberg HM, Jane JA, Luerssen TG, Marmarou A, Foulkes MA: The outcome of severe closed head injury. J Neurosurg 75 (Suppl) : S28-S36, 1991.

14）益澤秀明，久保俊朗，金沢 至，神谷 博，中村紀夫： 傍矢状部白質-脳梁-基底核損傷-びまん性軸索損傷に伴 う㾏性片麻盘の画像所見。脳外 25：689-694, 1997.

15) Memon MY, Paine KWE: Direct injury of the oculomotor nerve in craniocerebral trauma. $J$ Neuro. surg 35: 461-464, 1971.

16) Sherrington CS: Decerebrate rigidity, and reflex coordination of movements. J Physiol (Lond) 22:319332, 1898.

17) Wilson SAK: On decerebrate rigidity in man and the occurrence of tonic fits. Brain 43:220-268, 1920.

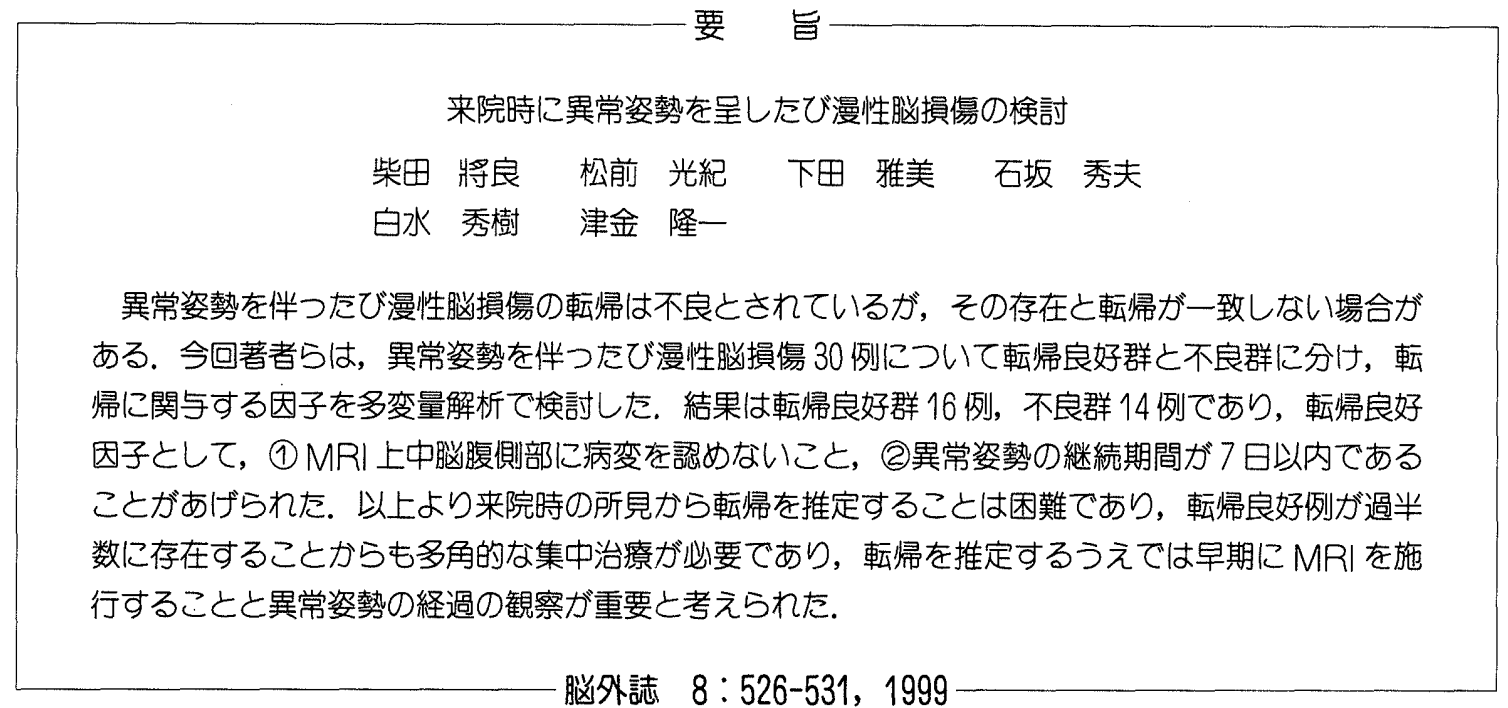

